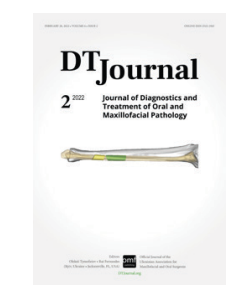

BUSINESS: EDITORIAL

Ivan V. Nagorniak, MSc, PhD, Section Editor

\title{
| One Million Dollar Private Practice
}

\author{
Nataliia M. Koba \& Ivan V. Nagorniak, ${ }^{b}$ *
}

The buyer will always think the value is overstated, and the seller will always think that the value is understated. ${ }^{1}$ -W. Paul Woody

Founder of Woody and Associates Work with over 260 dentists

Someday the owner of the private dental and oral surgery practice can decide to sell it. In some cases, this is because the owner wants to move away from dental matters completely; To move away from business not only as a dentist or oral and maxillofacial surgeon but even as a shareholder. Regardless of personal motives for the sale, the deal and the cost of whole practice should not be underestimated.

The price is to be based on a correct calculation of the next dental clinic data: Human resources (number of specialists, types of their specialization, experience, etc.), number of dental chairs, equipment, package of state permits for dental business and types of dental specialties that are included in the license of this clinic to conduct business in medical practice, presence of ISO 9001 certification for the clinic, established connections with partners (dental technicians, companies of dental products and equipment, insurance companies, etc.), types of diagnostic, treatment, and prophylactic procedures

Kyiv, Ukraine

${ }^{a}$ MSc; Former Head Doctor, Scientific Center of Dentistry and Ultrasound Surgery, Limited Liability Company.

${ }^{\mathrm{b}} \mathrm{MSc}, \mathrm{PhD}$; Head Doctor, Private Entrepreneur Nagorniak I.V.

Author's address: Private Practice (Certificate for management system according to ISO 9001:2015 - Private Entrepreneur Nagorniak I.V.), 6-G Andruschenka Street, Office 6, Kyiv 01135, Ukraine.

E-mail: ivan.nagorniak@gmail.com carried out in the clinic, base of clients, availability of consulting doctors, existence of communications with University chairs and associations/societies, presence of cooperation agreement with Pathology Department, location of the branch of the chair on the basis of the clinic, number of years at the market, longevity of the same team (Woody [2018] notes that 10-plus years for the same team is one of the best indicators for buyers), ${ }^{1}$ the size of real estate, location in the country and in the city/village (distance from the neighboring countries, airports, metro stations, and other transport nodes), the commercial real estate is owned or leased, real estate is a separate building or included to the multiple apartment building, presence of the rooms for the educational or hands-on training, courses that have been performed on the basis of this clinic, team experience in organization of the dental meetings, a state and international reputation of the practice, etc.

The professionals who are only planning to launch a private practice in Ukraine and are choosing the legal form must understand that business in a form of Private Entrepreneur (fizychna osoba-pidpryiemets [in Ukrainian] $)^{2}$ cannot be bought by another person or divided between shareholders. And due to that reason, if the founder of the private clinic wants to
Please cite this article as: Koba NM, Nagorniak IV. One million dollar private practice. J Diagn Treat Oral Maxillofac Pathol 2022;6(2):30-1.

Paper received 16 February 2021

Accepted 16 February 2021

Available online 22 February 2022

https://doi.org/10.23999/j.dtomp.2022.2.2

(C) 2022 OMF Publishing LLC. This is an open access article under the CC BY license (http://creativecommons.org/licenses/by-nc/4.0/). 
have the option in future to sell the business he/she should register the business in a form of Limited Liability Company (tovarystvo $z$ obmezhenoiu vidpovidalnistiu [in Ukrainian]) or Private Enterprise (pryvatne pidpryiemstvo [in Ukrainian]). ${ }^{2}$

Another key for the success practice sell is to avoid the doctor's name in a clinic's name (Goldsmith, 2018). ${ }^{3}$ So, if the name of the practice is the doctor's one, the practice value may be less in these situations. ${ }^{2}$ Such conclusion is supported by the evidence that $40 \%$ of patients leave a practice once the doctor with the branded name is gone. ${ }^{2}$

Palmerino (January 2018) emphasized 4 things the practice owner should know when thinking of selling the dental practice: (1) start early (because a selling process typically takes years), (2) to have realistic expectations about what the practice is worth (do not have an inflated view), (3) keep essential equipment and facilities up to date, and (4) to understand that sale doesn't always mark the end of the road (in some cases the buyers can motivate previous owner to continue doing practice 1 year after the deal).

Goldsmith in July 2018 described 5 ways to maximize return on investment (ROI) when selling the dental practice: (1) to avoid doctor's name is a clinic title, (2) build a strong structure, (3) systems keep things organized (buyers avoid purchasing of disorganized practice), (4) handling the owner's paycheck, (5) keep a sharp eye on expenses and profits.

Interestingly, that seller can choose keeping their commercial real estate so it can continue to generate rental income.

Worth of attention is the fact that by taking unsolicited offer, the seller may miss an opportunity to make a deal with a partner who will make much better proposal.

In conclusion, when the practice owner will calculate all the dental clinic data it may be noted that even a small dental clinic with one dental chair may be worth of $\$ 1$ million USD or even more. Our humble advice for the dentists who wish to open a new dental clinic or to grow the existed one is to leave an option of its future sell. It doesn't matter if we make that decision in the future, it's always great when we have more options in our life.

$$
\begin{array}{r}
\text { One today is worth two tomorrows. } \\
\text { - Benjamin Franklin } \\
\text { One of the Founding Fathers of the USA }
\end{array}
$$

\section{REFERENCES (5)}

1. Woody PW. How to make your dental practice more valuable at the time of sale [document on the internet]; May 01, 2018 [cited 2022 Feb 05]. Available from:

https://www.dentaleconomics.com/practice/ article/16385122/how-to-make-your-dentalpractice-more-valuable-at-the-time-of-sale

2. Koba NM, Nagorniak IV. Ukraine: legal forms for private practice in oral surgery and dentistry. J Diagn Treat Oral Maxillofac Pathol 2021;5(9):97-8. https://doi.org/10.23999/j.dtomp.2021.9.1

3. Goldsmith A. 5 ways to maximize ROI when selling your dental practice [document on the internet]; Jul 30, 2018 [cited 2022 Feb 06]. Available from:

https://www.dentistryiq.com/practice-management/ practice-management-tips/article/16367769/5-waysto-maximize-roi-when-selling-your-dental-practice

4. Palmerino M. Thinking of selling your dental practice? 4 things you should know [document on the internet]; Jan 16, 2018 [cited 2022 Feb 07]. Available from:

https://www.dentistryiq.com/practice-management/ practice-transitions/article/16367487/thinking-ofselling-your-dental-practice-4-things-you-shouldknow

5. Cumbus KG. Think twice before entertaining an unsolicited offer for your business. Compend Contin Educ Dent 2022;43(1). 